\title{
THE HISTORICAL ROLE OF LIBRARIES IN SCHOLARLY COMMUNICATION
}

\author{
BY PAMELA SPENCE RICHARDS
}

Dr. Richards is Associate Professor in the School of Communication, Information and Library Studies, Rutgers University.

$7 \mathrm{HE}$ IDEA of the library as a center of scholarship is ancient and widespread, but modern sociologists and historians of science have

1 recently emphasized how much of scholarly communication goes on outside of libraries: Harriet Zuckerman has demonstrated the importance of the teacher, and of the network of colleagues, in the passing on of scholarly standards. ${ }^{I}$ Diana Crane has shown how modest a role in the diffusion process is played by libraries, which are less influential and far less immediate than teachers, networks of colleagues, manuscript circulation, conferences and preprint circulation. ${ }^{2}$ In fact, it can be as much as several years after an idea's original conceptualization that an article presenting the idea is actually published in a journal, thus making the idea accessible in the library.

In these pages I will try to show that all of these non-print methods of scholarly information transfer, although unquestionably vital and preliminary to diffusion through books and journals, are, in their international functioning, extremely vulnerable and can suffer critical curtailment in times of war. I will focus particularly on the period of the Second World War, when, as a result of the almost total breakdown of the various interpersonal methods of scientific and scholarly exchange between the Axis and Allied countries, scholars were forced to rely on printed material in libraries. So clear did this dependency become to governments on both sides of the conflict that when the international book trade itself began to falter, official emergency information-gathering networks were instituted. We will see that in both Germany and the United States this process raised the consciousness of the central authorities to the strategic importance of libraries and had an effect on postwar developments in library planning.

${ }^{2}$ Harriett Zuckerman, Scientific Elite: Nobel Laureates in the United States (New York: Free Press, 1977).

${ }^{2}$ Diana Crane, Invisible Colleges: The Diffusion of Knowledge in Scientific Communities (Chicago: University of Chicago Press, 1972). 
The Increase in International Scholarly Communication in the Nineteenth and Early Twentieth Centuries

Before we describe the breakdown in interpersonal international scientific and scholarly relations occasioned by the outbreak of the Second World War, it is useful to look at developments in this area since the nineteenth-century revolution in communications. It is probably unnecessary to review here those developments in the book trade such as steam printing ( I 8 I 4 ) and the introduction of wood pulp paper ( $185 \mathrm{I}$ ) which made books so much more numerous and inexpensive, but it is useful to point out that the same technological progress that brought improvements in the book trade also brought about increased interpersonal scholarly communication. Steam harnessed to ships-and to canal-building machinery - meant that large numbers of men and women of different cultures could actually meet and converse regularly. In the nineteenth century we see for the first time a situation where international voyages by scholars and scientists became fairly usual: The London Exhibition of I $85 \mathrm{I}$ is perhaps the best known early symbol of the new personal form of international technical and scientific exchange, but James Morris has shown in his magnificant trilogy on the British Empire ${ }^{3}$ what an important conduit modern imperial systems could be for the international movement of scholars, both from and to Europe.

Colonial networks were of course not the only frameworks within which nineteenth-century scholars circulated internationally, even if they were perhaps the most colorful, Of enormous importance to the development of American universities and their libraries was the trend, begun early in the century by members of Boston's upper class, of young Americans going to German universities to study. ${ }^{4}$ By the 1870 , enough American graduates of Göttingen and Berlin had returned to their homeland to demand and implement, with the founding of Johns Hopkins University in Baltimore in 1876 , the establishment in the United States of a research university on the German model. To this day American higher education owes more to German than English precedents.

The early twentieth century saw increased interpersonal international scholarly contacts as speedier sea and, eventually, air travel was introduced. "Internationalism," here meaning the advocacy of the universality

3 James Morris, Pax Britannica (New York: Harcourt Brace and World, i 968); Heaven's Command (New York: Harcourt Brace Jovanovich, 1973); Farewell the Trumpets (New York: Harcourt Brace, 1978).

${ }_{4}$ David B. Tyack, George Ticknor and the Boston Brahmins (Cambridge: Harvard University Press, 1967). 
of scholarship, became during the first three decades of the century a favorite tenet of many Western intellectuals, including the American library pioneer Melvil Dewey. This internationalism, so profoundly disappointed by the carnage of the First World War, was the spirit behind the founding of various private and government-funded institutions which were to play an important role in encouraging interpersonal international scholarly communication in the I 920 ; these included the League of Nations' Committee on Intellectual Cooperation (1922) and, in the United States, the charities of financier Andrew Carnegie, especially the Carnegie Corporation.

All during this period, national library resources for scholars grew in size and complexity, profiting from technological improvements in the book trade and international communications to broaden their international periodical and monograph collections. What is of interest to us here is that in the late nineteenth and early twentieth centuries, while many leading scholars and scientists were becoming more international in their orientation and activity, research libraries were acquiring the role of symbols of national greatness, even as their collections became more international. New national library buildings opened during this period-the U.S. Library of Congress (I 897) and the Prussian Royal Library ( I 9 I4)-had more than just scholarly dignity; they had become symbols of national cultural grandeur. Perhaps the most dramatic example of the symbolic national value of a great library is offered by the checkered career of the municipal library of Strasbourg, destroyed by the Germans in I 870 , reconstructed by them into a great German state library between I 87 I and I9I4, and, after World War I, vaunted proudly by the French as their second largest library.

\section{The Impact of World War II}

What, then, was the impact on these two parallel scholarly communication systems - print and interpersonal —of the six-year severance of relations between the Allied and Axis nations brought about by World War II, and why was the impact different from that of the First World War? First, it should be pointed out that organized interpersonal international communication had increased enormously between I 9 I 8 and I 939 due to developments in radio, air mail and air travel, so that their curtailment in I 939 would be more radically felt than in I 9 I 4 . In librarianship alone, for example, we see the International Association of Library Associations (IFLA) being founded in 1929, and the International Federation of Documentation (FID, before I93 I the International Institute of Bibliog- 
raphy) becoming a truly international organization only in the late I 920 . Perhaps the period's high point of interpersonal cross-cultural information transfer in librarianship came at the 1937 International Federation of Documentation meeting held in conjunction with that year's Paris Exposition: large delegations from all the developed countries and some emerging nations were on hand to hear Germany's Andreas Krüss extend the invitation to the FID to hold its I 940 meeting in Mainz, Germany, in connection with that year's planned Gutenberg Jubilaeum. ${ }^{5}$ That meeting was, of course, never held. Furthermore, the invasion of the Low Countries and France in I 940 saw the occupation of the headquarters of both the library profession's international organizations, which suspended operations for the duration of the war.

Conferences were not, of course, the only type of interpersonal international scholarly communication that saw increased activity after World War I: During this period many European and American professional and scholarly organizations sponsored foreign study, even during the Depression; in librarianship, the Carnegie Corporation sent a number of women to American library schools, from which they returned to accelerate development in such countries as France, Australia and New Zealand. The Carnegie Corporation was also important as a sponsor of international consultancies: it underwrote the investigative trips of American and British librarians to South Africa (1928) and Australia and New Zealand ( I 934); in each case the published reports which followed these visits led to the beginnings of modern librarianship in those countries. ${ }^{6}$

One ancient means of scholarly communication, the migration of intellectuals, experienced a tragic revival in the I930s: Racial laws passed in Germany in April I 933 to purge the German civil service of Jews and dissidents resulted in the loss to Germany of some of its most eminent professors. Ultimately twenty Nobel laureates were forced to resign, all but one of whom left the country. ${ }^{7}$ The most famous refugee was unquestionably Albert Einstein, but the host countries (mainly England, Switzerland and the United States) received stars from many disciplines: Erwin Panofsky and his compatriots made New York University's Institute of Fine Arts a world center for art history from the late I930s, and the

${ }_{5}$ Dokumentation und Arbeitstechnik (May 1939), p. I.

${ }^{6}$ Pamela Spence Richards, "Information for the Allies: Office of War Information Libraries in Australia, New Zealand and South Africa," Library Quarterly 52 (October 1982): 325347 .

7 Alan D. Beyerchen, Scientists under Hitler (New Haven: Yale University Press, I 977), p. 47. 
Warburgs' famous library, relocated from Hamburg, gave London an important cultural history resource. The scholarly communication dynamic begun by this "cultural migration" is still part of the host countries' intellectual life, for scores of these scholarly emigrants, many of them Nobel Prize winners, went on to teach hundreds of students, some of whom in turn became themselves Laureates and are now teaching a new generation.

Thus, interpersonal international scholarly activity was at unprecedented heights before the outbreak of World War II. What, then, was the situation with scholarly print communication? Here international interdependence had been greatly increased after I9I8. Before the first World War Germany had dominated scientific publishing, with its great reviews such as Chemisches Zentralblatt unrivaled. But the American Chemical Abstracts, founded in I 907, and Biological Abstracts ( I 926) soon had large European audiences. Even the German National Socialist government, whose public position was that foreign research was irrelevant to German scholarship, was forced soon after its assumption of power to acknowledge the internationality of science: When, after 1 936, all library orders of foreign materials had to be routed through the Gestapo for clearance, the Gestapo consistently granted the foreign credits necessary for the purchase of foreign scientific and technical journals to its specialized research libraries, lest otherwise Germany's defense industries fall behind; ${ }^{8}$ further, an elaborate information center was set up at the library of the Technological University at Berlin-Charlottenburg to translate, abstract, index and disseminate the contents of foreign journals. In America and England, all collections, not just those in applied and pure science, became increasingly international: by 1939 the United States was paying $\$$ I. 5 million annually for foreign literature, of which by far the largest part came from Germany. ${ }^{9}$

Upon the outbreak of the war, termination of interpersonal scholarly communication between the belligerents was swift and inevitable, but both sides of the conflict responded imaginatively to the threat, and then the realization, of a collapsed international scholarly book trade. The neutral countries of Portugal, Sweden and Turkey became the locations of camouflaged addresses to which subscriptions of German, Dutch, American, English and French scientific and technical periodicals were sent,

\footnotetext{
${ }^{8}$ Pamela Spence Richards, "German Libraries and Scientific and Technical Information in Nazi Germany," Library Quarterly 55 (April I 985): 15 I-1 74.

9 U.S. Office of Alien Property Custodian, "Report to the President on the Periodical Republican Program," mimeographed, Washington, DC, I 945.
} 
and a small industry of clandestine photographers grew up in Lisbon, Stockholm and Istanbul to serve the rival intelligence services. From these points, single copies or microfilms of the enemy's journals were flown to New York or Berlin (Lufthansa maintained weekly flights from Lisbon and daily flights from Spain into 1945), where they were further disseminated domestically. ${ }^{\text {10 }}$

The Germans used the existing information center at the Technological University at Berlin-Charlottenburg, together with that of the World Economics Institute at Hamburg, as their main dissemination points. In collaboration, the two centers published from I 942 to November I 944 a monthly review journal containing around 3,000 abstracts, in translation, of European, American and British scientific and technical journal articles. The selected libraries receiving the abstracts could order the articles from Berlin-Charlottenburg. To further expedite the processing of printed foreign scientific and technical information, the German government in I 94 I founded the German Society for Documentation; in 1943 the Society published an inventory of all foreign materials to have entered Germany since September 1939. Despite the total destruction by bombing of the Technological University at Berlin-Charlottenburg in I 943, and the fire-bombing of Hamburg, the review of foreign journals continued to be published until late I 944 . Some of this material was of surprising strategic value. Notes released in the March and April I 940 issues of Physical Review revealed that experimental proof had been found that slow neutrons had a greater probability of fissioning enriched uranium; and in the June I 940 number of the same journal, just before all such research was classified, the discovery of plutonium was announced. Thus German scientists learned the results of physical investigations which they did not have the means to obtain themselves. "I

The American government was slower than the Reich to construct an emergency supply network for foreign scientific publications. During the two years of US neutrality, it was left to America's library associations to cope with the breakdown of regular channels, and a Committee on Importations was established in 1939 to coordinate shipments from the diminishing number of neutral ports. After America's entrance into the war, restrictions on currency dealings with the enemy made this arrangement impossible, and importation of books and journals was taken over by the American intelligence branch, the Office of Strategic Services

to Coblenz, Federal Republic of Germany, Bundesarchiv. File NS 6/440.

" David Irving, The German Atomic Bomb (New York: Simon and Schuster, 1967), pp. $70-72$. 
(OSS). In 1942 the OSS set up an Interdepartmental Committee for the Acquisition of Foreign Publications, whose task it was to arrange for the clandestine acquisition abroad of single copies of key scientific and technical journals published in Germany or the occupied countries. The list of desired journals was composed by an advisory committee of prominent librarians. The copies were flown from Sweden and Portugal to London and thence to the US, where, under a special arrangement with the Department of Justice's Alien Property Custodian, they were reprinted and distributed to public, academic and industrial research libraries and government agencies also in England. A few of these articles were of critical importance: in I 943 the Republication Program had reprinted eleven papers on atomic experiments published in 1942 and 1943 issues of Zeitschrift fïr Physik and Die Naturwissenschaften after the Germans had decided that the bomb was not practical for immediate development. It was these articles, written by Otto Hahn and his associates, to which E. J. Crane, wartime editor of Chemical Abstracts, referred when he told those responsible for the reprinting that "your republication program was one of the factors which made the atomic bomb possible." ${ }_{12}$

The amount of exchange of printed technical and scientific information among the allies was quite varied: German-Japanese and German-Italian scientific collaboration never really developed, largely because of German convictions that their allies were not their technological peers. AngloAmerican cooperation, on the other hand, was active after a I94 I treaty in which the two countries agreed to share technical and scientific information: British advances in radar were shared with the American air force, and American reprints of German articles were regularly distributed to British libraries. Not only did this cooperation obtain in most defense-related research, but also in the area of civilian information needs: Between 1942 and 1945 the US Office of War Information operated libraries in the British Commonwealth as well as in neutral countries for the free use of the local citizenry. The libraries, which later became the core of the US Information Service, contained current American publications on whatever industries were locally important. For some people in some of the cities served, these publications represented the only current technical information available. ${ }^{13}$

The Russians occupied an interesting position in the Allied print information exchange network: In 1942 , in an effort to compensate somewhat

12 Pamela Spence Richards, "Gathering Enemy Scientific Information in Wartime," Journal of Library History I6 (Spring I98 I): 262.

13 Richards, "Information for the Allies . . . ," p. 339. 
for their failure to open a second front that year, the British concluded a treaty with the Russians whereby the British would share with them information about their war inventions. The British need to sustain the Russian front was so great that a plan was drawn up by which the physicist and radar expert Henry Tizard would operate a permanent scientific liaison office in Moscow. The Germans were at this time deep in Russian territory, and the prospect of the loss to Germany by the Russians of Allied military secrets so terrified the Americans that they began to hold scientific information back from the British, lest it fall into Russian, and thence into German, hands. By I 944, however, with Germany almost defeated and three more years predicted for the war in the Pacific, American desire to defeat Japan prompted a reversal of her policy towards Russia, and American technical information began to flow more freely. But, despite an ultimately large influx of British and American printed and processed technical manuals and reports into the Soviet Union, and even some travel by Soviet officials to sites in Britain, the verdict of historians seems to be that scientific and technical communication between Russia and her Western allies was not adequate enough to make a real difference to her, largely because of the constant disagreement between Britain and America as to how much information to share. ${ }^{14}$ Certainly there are no records to indicate that German articles seized and reprinted by the United States made their way to the USSR as they did to Britain.

But for Germany and the United States, the perception of the value of foreign scientific information to each country's war effort was critical to postwar planning for technical information dissemination. In a period when interpersonal international scholarly communication was severely limited, the importance of the print medium had been high-lighted. Both in America and Germany, centralized government agencies used existing research libraries as the depositories and dissemination points for foreign publications. The United States even founded a new chain of libraries overseas to serve as conduits for civilian technical expertise. We will see that after the war, both countries took steps to institutionalize heightened awareness of the strategic importance of libraries.

In America, use of libraries for war-related research had made the inadequacies of foreign holdings painfully obvious. I 948 saw the formulation of the Farmington Plan, a division of foreign acquisitions responsibilities among the nation's research libraries to ensure that in the future

${ }^{14}$ E. H. Beardsley, "Secrets Between Friends: Applied Science Exchange Between the Western Allies and the Soviet Union during World War II," Social Studies of Science 7 ( 1977 ): 468. 
the United States would own at least one copy of each important foreign title. The government stayed in the foreign information acquisition business after the war as well. The Office of Technical Services (later the National Technical Information Service) was founded in 1946 to translate and process captured German documents, and later in 1962, Public Law 480 was amended to permit the use of surplus foreign currency overseas for the purchase of local publications in a number of developing countries. The US government also stayed in the business of disseminating technical information abroad: the Office of War Information Libraries ultimately became part of the United States Information Agency, founded in 1953 .

Postwar developments in Germany were complicated by political divisions. Philosophically opposed to cultural centralization, the West Germans further developed some of the features of the pre-National Socialist period, such as a cooperative acquisitions program and an interlibrary loan system. Despite the federated structure, certain national information institutions have evolved. Significantly, the first of these to be founded was the central Technical Information Library at Hanover (1959). In East Germany, where central planning was at the heart of the new socialist state, the foundations for centralized processing of foreign information date almost to the beginning of the Democratic Republic itself. In I 950 the Center for Scientific Information was founded in Berlin and performed essentially the same abstracting and disseminating tasks as had the old Technological University at Charlottenburg. In 1955 these functions were taken over by the Institute for Documentation attached to the German Academy of Sciences. An indication of the importance attached to the Documentation Institute's function was its transfer in I 964 to the jurisdiction of the State Secretary for Research and Technology. ${ }^{\text {I5 }}$

Interestingly, Russia, the country which, of the three studied, derived the least advantage from foreign information sources in wartime, was the one to put least emphasis on their acquisition and domestic dissemination in the period right after the war. In fact, the immediate postwar years saw a real cutback on foreign literature coming into the USSR: In I 950 the Academy of Sciences received fewer foreign publications than it had in 1940, and four times fewer than it had in $1936 .{ }^{16}$

But in the West anyway, during the conflict that ended forty-odd years

is Achim Beyer, "Information und Dokumentationswesen," in Wissenschaft in der DDR (Erlangen: Institut für Gesellschaft und Wissenschaft, 1973), p. 206.

${ }^{16}$ Bruce Parrott, Politics and Technology in the Soviet Union (Cambridge: MIT Press, I983), p. I I I. 
ago, libraries had passed from symbols of cultural grandeur to become fortresses in a line of defense, with contents of international strategic importance. It remains to be seen whether this should be considered an altogether favorable development. Up until recently it has seemed such, given the increasing resources poured into libraries in the West after the war. But recent restrictions in the United States placed by the Reagan Administration on interpersonal scholarly communication ${ }^{17}$ may be a warning that the vaunting of the strategic value of information has dangers for libraries as well: it may lead to a kind of paranoia that imperils the free exchange of scholarly and scientific ideas in any form, including books. I have hoped in this paper to demonstrate the historical connection between interpersonal and print scholarly communication. It is clear to me at least that professionals of the print media, librarians as well as journalists and publishers, must resist infringements on interpersonal scholarly communication as energetically as they would censorship of printed communication.

17 The Department of Defense Authorization Act of I 984 (DOD directive 5230-25) authorizes the Secretary of Defense to restrict access to unclassified data with military or space applications. That authority was used publicly for the first time in April I985 during a meeting of the Society of Photo-Optical Instrumentation Engineers. See Janice R. Long, "Scientific Freedom: Focus of National Security Controls Shifting," Chemical and Engineering Newes 63 (I July 1985): 7-I I. 